\title{
NOTES
}

\section{LOSS DISTRIBUTION IN WAR-TIME IMPOSSIBILITY OF PERFORMANCE*}

WHEN a change of circumstances due to war-time conditions makes contract performance a substantially different undertaking from that contemplated by the parties, the defendant in an action for breach of contract may invoke the defense of impossibility of performance. ${ }^{1}$ This defense, which arose in response to the harshness of the early common law, ${ }^{2}$ has been expanded to include bargains whose performance is impracticable, though not strictly impossible. $^{3}$ The impossibility doctrine, however, has been substantially qualified by the foreseeability test. ${ }^{4}$ Courts universally hold that when the defendant alone could have foreseen the impossibility, he cannot escape liability. Many hold that the defense is equally unavailable when the impossibility was foreseeable by both parties. ${ }^{6}$ Only when the defendant could not have foreseen the circumstances is impossibility always a good defense. ${ }^{7}$

Whenever the impossibility defense is sustained, plaintiff loses the benefit

\# L. N. Jackson \& Co. v. Royal Norwegian Government, 177 F.2d 694 (2d Cir. 1949); 1 SYRACUSE L. REV. 497 (1950); 98 U. oF PA. L. REv. 592 (1950).

1. The leading American case is The Kronprinzessin Cecile, 244 U.S. 12 (1917). The impossibility defense itself is a relatively recent development in contract law, having first been applied in Taylor v. Caldwell, 3 B \& S 826 (K.B. 1863). Its first use in vartime was in World War I, 6 Whurston, Conrracts $\$ 1938$ (Rev. ed. 1938). The defense may be based on a change of law or an administrative order rendering performance impossible even though the defendant was active in bringing that change about. See Mlawhinney v. Milbrook Woolen Mills, 231 N.Y. 290, 132 N.E. 93 (1921) ; 6 Wrrursto:; Co:stunets $\$ \S 1938,1939$ (Rev, ed. 1938):

2. The severity of the common law rule of Paradine v. Jane, Aleyn, 26 (1646), that a contract is absolutely binding on the promisor, was illustrated in Hills v. Sughrue, 15 11. \& W. 253 (1846), where a contract to load a full cargo of guano at a given island was enforced, although there was not enough guano on that island for such cargo.

3. The expansion of the concept beyond absolute impossibility has long been recognized. E.g., Dahl v. Nelson, Donkin, \& Co., 6 App. Cas. 38 (18s1); Mineral Park Land Co. v. Howard, 172 Cal. 2S9, 156 Pac. 458 (1916).

4. E.g., Chicago, M. \& St.P.Ry. v. Hoyt, 149 U.S. 1 (1892) ; Mradeirense Do Brasil S/A v. Stulman-Emrick Lumber Co., 147 F.2d 399 (2d Cir. 1945).

5. 6 Williston, Contracts $\$ 1959$ (Rev. ed. 1938), and cases cited.

6. Companhia De Navagacao Lloyd Brasileiro v. C. G. Blakie Co., 34 F.2d 616 (2d Cir. 1929) (impossibility defense unavailable where strike which caused the impossibility known to both parties at time of contract); Glens Falls Indemnity Co. v. Perseallo, -Cal.2d-, 216 P.2d 567 (1950) (impossibility no defense since performance-defeating government regulations foreseeable to all Americans at time of contract).

Other courts, however, allow the impossibility defense where the contingeney was clearly foreseeable to both parties. E.g., The Kronprinzessin Cecile, 244 U.S. 12 (1917) (outbreak of war a few days later excused non-performance of a contract entered into on July 27,1914$)$.

7. Restatenient, Contracts $\$ \$ 456,457$ (1932). 
of his bargain and bears whatever "out-of-pocket" losses he has suffered in reliance on the contract. When liability is imposed, he may receive not only reliance damages, but also expectation damages for anticipated profits lost due to the breach. ${ }^{8}$

L. N. Jackson \& Co. v. Royal Norwegian Govermment ${ }^{0}$ raised squarely the problems of war-time impossibility. Defendant contracted to carry a cargo of copra for plaintiff from East Africa to New York, and in reliance on this booking, plaintiff contracted to buy the copra. Prior to the booking, defendant had submitted to the Ship Warrants Act. ${ }^{10}$ Under this Act, the Norwegian Government agreed to accept United States Maritime Commission orders as to cargoes, voyages, and rates in exchange for priorities in the use of Americancontrolled harbor facilities. ${ }^{11}$ Subsequent to the booking, but before the copra was loaded, the United States entered World War II, and the Maritime Commission ordered the defendant to carry wool instead. ${ }^{12}$ Defendant complied, and when sued for breach of contract, argued that the administrative order made performance of the copra-carrying contract impossible.

In denying recovery, the Second Circuit Court of Appeals found that the parties had equal knowledge of the situation. Both knew of defendant's participation in the warrant system, ${ }^{13}$ and hence, the court felt, defendant was under no obligation to protect himself by express stipulation against the system's operation. Neither party, however, could have foreseen the Pearl Harbor attack which was the immediate cause of the Maritime Commission's order. The court further noted the fragmentary nature of the contract, which did not

8. MCCORMICK, LAW of DaArages $\$ 137$ (1935). Plaintiff can recover only genteral damages as a matter of course. Any recovery for special damages he may have suffered is limited by such rules as those barring recovery where damages are speculative in mature, $i d$. $\$ \$ 25-8$, or where the loss was not reasonably foreseeable to the defendant at the time the contract was made, $i d$. $\$ 138$.

9. 177 F.2d 694 (2d Cir. 1949).

10. 55 Stat. 591 (1941).

11. There were coercive pressures to submit to the Warrant system, as was pointed out when the Act was passed: "No man must go and get a warrant for his vessel, but if he does not get a warrant, it means that he is foreclosed so far as certain facilities are concerned, so far as docks and wharves and fuel and loading facilities are concerned. So there is the indirect pressure by which vessel owners must go and get themselves a warrant from the Maritime Commission." Rep. Dirksen, 87 CoNG. REc. 4288 (1941). Furthermore, as a government in exile, the Norwegian government was in a poor position to defy orders of the United States Government.

12. Failure to obey would have subjected defendant both to loss of his prioritics on harbor facilities and to criminal penalties, 55 STAT. 591, 592 (1941).

13. 177 F.2d 694, 699-700. Factually, this conclusion seems sound, although Judge L. Hand, dissenting, was unconvinced that plaintiff had any knowledge that defendant was under the Ship Warrants Act, id. at 702. In view of the fact that this act was the "most important development" in American shipping at the time, $i d$. at 699, and the fact that the contract showed on its face that it was being forwarded to the Maritime Commission, L. N. Jackson \& Co. v. Lorentzen, 83 F. Supp. 486, 488 n.1 (S.D. N.Y. 1949), it is difficult to see how plaintiff could have been unaware of the situation. 
purport to set forth the obligations of the parties in detail. 14 These considerations led the court to the conclusion that "fairness and justice" required that defendant's non-performance be excused. ${ }^{15}$

But there is no compelling reason why it is more "fair and just," in the Jackson situation, to place the full risk of loss on plaintiff than defendant. It could be argued with equal force that, although the parties were in an equal position to foresee impossibility, the shipowner would be the non-performing party should that impossibility occur; and therefore it was his duty to provide expressly against the risk.

Furthermore, foreseeability is a matter of degree. ${ }^{10}$ This makes it especially easy for a court to resolve foreseeability either way when the impossibility is of such a nature that the parties are bound to be in the same position-i.e., both able to foresee or both unable to foresee. Yet the results may be opposite depending on which is chosen. If both are unable to foresee, impossibility is a good defense. ${ }^{17}$ If both are able to foresee, many courts reject the impossibility defense despite the fact that either party could be held to have knowingly assumed the risk. ${ }^{18}$

The inconclusiveness of the foreseeability test is heightened by confusion among American courts as to which party must bear the burden of proof on that issue. $^{19}$ In the Jackson case the majority apparently required plaintiff to prove that impossibility was foreseeable to the defendant alone, ${ }^{20}$ while Judge Hand in his dissent insisted that the defendant must show that it was not. Since ordinarily neither party can conclusively prove or disprove foreseeability, any result can be justified on the ground that the losing party did not sustain his burden of proof.

14. The contract stated only the amount to be shipped, the price, and the time of payment 83 F. Supp. 486,488 n.1 (S.D. N.Y. 1949).

15. 177 F.2d 694, 699.

16. Felder v. Oldham, $199 \mathrm{Ga} .820,35$ S.E.2d 497 (1945) (war always foreseeable, therefore impossibility due to wartime labor shortage is no defense). Compare Berg $v$. Erikson, 234 Fed. 817 (8th Cir. 1916) (unprecedented drought a foresceable contingency), zeit/z Ontario Deciduous Fruit-Growers' Ass'n v. Cutting Fruit-Paching Co., 134 Cal. 21, 66 Pac. 28 (1901) (drought unforeseeable). And see Williston's statement: "Any kind of impossibility is more or less capable of anticipation. The question is one of degtee. .. ." 6 WIIIISton, Contracts $\$ 1953$ (Rev. ed. 1938).

17. See note 7 supra.

18. See note 6 supra.

19. Some cases apparently place the burden of proving non-foreseeability on the defendant. Companhia De Navagacao Lloyd Brasileiro v. C. G. Blake Co., 34 F.2d 616, 619 (2d Cir. 1928) ; Lloyd v. Murphy, 25 Cal.2d 48, 153 P.2d 47, 50-52 (1944). But the language used in other cases indicates that the burden of proving foresceability rests on the plaintiff. The Kronprinzessin Cecile, 244 U.S. 12, 22, 24 (1917); Tesas Co. v. Hogarth Shipping Co., 256 U.S. 619, 631 (1921).

20. In reaching this result, the court followed the English rule that once impossibility is shown, plaintiff must prove an exception to the defense. See Joseph Constantine Steamship Line, Itd. v. Imperial Smelting Corp., Ltd. [1941] 2 All E.R 165, rcuersing [1940] 3 All E.R. 211, noted in 19 CAN. B. KEv. 612 (1941). 
The greatest difficulty with the impossibility defense, however, is the "all-ornothing" rule of damages. ${ }^{21}$ This leads to an unfair result in many cases no matter how the foreseeability doctrine is applied. Thus plaintiff may be denied any recovery, or allowed full recovery when he deserves part; either alternative is unfair where the parties are equally innocent. ${ }^{22}$ In the Jackson case neither result would be satisfactory in view of the patent impossibility of performance on the one hand, coupled with plaintiff's reliance losses and defendant's stubstitute contract on the other.

A less doctrinal approach would treat the defense of impossibility as a plea of "excusable breach." The defense should not prevail where the defendant alone knew, or reasonably should have known, that there was a substantial likelihood of impossibility. In this limited situation the defendant should be liable for plaintiff's "out-of-pocket" expenses and anticipated profits lost duc to the breach. ${ }^{23}$ Conversely, if the plaintiff alone was in a position to foresee the impossibility, that fact should constitute a complete defense. But where plaintiff and defendant were in an equal position to anticipate difficulty, liability should be treated as essentially a problem of loss distribution, ${ }^{24}$ based on the parties' economic position resulting from defendant's non-performance. ${ }^{25}$ If the plaintiff suffered no "out-of-pocket" losses as a result of the breach, no recovery should be allowed since plaintiff has sustained no actual loss. Similarly, unless the defendant obtained a profitable substitute contract in connection with the impossibility, the burden should be left as it fell, since he

21. See page 1512 stpra.

22. For a general discussion, see Fuller \& Perdue, Reliance Interest in Contract Damages: $I, I I, 46$ YAlE L.J. 52, 373 (1936).

23. Since the defendant is entirely at fault, there is no reason for denying full recovery to the plaintiff. The policies of preventing and curing to the fullest extent the harms occasioned by his reliance, and of facilitating reliance on business agrcements, should therefore be given full sway. Cf. Fuller \& Perdue, Reliance Interest in Contract Damages: I, 46 Y ALE L.J. 52, 59-62 (1936).

24. Loss distribution is not entirely alien to American law, as is shown by the "general average" rule in admiralty, whereby the shipper and the owner share the loss in certain situations. See Robinson, Admiralty $\$ 103$ (1939). Further evidence of loss distribution is to be found in the comparative negligence statutes of Georgia, Mississippi, Nebraska, Virginia, and Wisconsin. See Prosser, Law of Torrs § 53, pp. 405-6 (1941).

25. The Second Circuit Court of Appeals has shown some willingness to fix liability on the basis of the ultimate economic position of the parties resulting from a breach. L. Albert \& Son v. Armstrong Rubber Co., 178 F.2d 182 (2d Cir. 1949) held inter alia that while promisee could recover his reliance losses, promisor could offset against him the amount promisee would have lost had promisor performed. See Note, 63 HARv. L. Rev. 1068 (1950).

26. This rule should also apply to cases where, subsequent to defendant's excusable breach, the plaintiff recovers his "out-of-pocket" losses from the market. Where plaintiff recovers part of those losses, that part should be subtracted from his total reliance loss.

It is recognized that defendant in this situation may have profited from a substitutc con- 